\title{
Inhibition of herpes simplex virus type 1 infection by Sambucus ebulus extract in vitro
}

\author{
Hadi Ghaffari ${ }^{1,2}$, Angila Ataei-Pirkooh ${ }^{3}$, Sayid Mahdi Mirghazanfari ${ }^{4}$, Mohammad Barati*1 $\mathbb{D}$ \\ Received: 1 Mar 2020 \\ Published: 18 Jan 2021
}

\section{Abstract}

Background: The emergence of drug-resistant strains of herpes simplex virus type 1 (HSV-1) has been increasingly reported. Therefore, attempts to discover new antiviral agents in particular from natural compounds are required. In this study, we evaluated the possible inhibitory effects of hydroalcoholic extract of Sambucus ebulus (S. ebulus) against HSV-1.

Methods: $S$. ebulus extract was produced by maceration method. MTT assay was used to evaluate the cytotoxicity effects of the $S$. ebulus extract; also, antiviral effects were measured both by test TCID50 and quantitative real-time PCR methods. To study the inhibitory impact of S. ebulus extract on the expression of HSV-1 antigens, indirect immunofluorescence assay (IFA) was also performed. All analyses were performed using the GraphPad Prism software v. 7.0.

Results: In the postexposure assay of HSV-1 with S. ebulus extract at the highest nontoxic concentration $(75 \mu \mathrm{g} / \mathrm{mL})$, S. ebulus extract led to $2.6 \log 10$ TCID50 reduction in infectious virus titer. At the highest nontoxic concentration, the S. ebulus extract led to inhibition rates of $91.2 \%$, based on the quantitative real-time PCR assay results $(\mathrm{p}<0.001)$. Also, in the immunofluorescence assay, a significant reduction was observed in fluorescence emission intensity in HSV-1-infected cell treated with S. ebulus extract compared to the control group.

Conclusion: S. ebulus extract is a novel and effective natural compound in reducing HSV-1 titer and future studies should be conducted to discover the complete mechanism of antiviral effect of this natural compound.

Keywords: Herpes simplex virus, Antiviral activity, Natural product, Sambucus ebulus

Conflicts of Interest: None declared

Funding: AJA University of Medical Sciences

\section{*This work has been published under CC BY-NC-SA 1.0 license. \\ Copyright $\subseteq$ Iran University of Medical Sciences}

Cite this article as: Ghaffari H, Ataei-Pirkooh A, Mirghazanfari SM, Barati M. Inhibition of herpes simplex virus type 1 infection by Sambucus ebulus extract in vitro. Med J Islam Repub Iran. 2021 (18 Jan);35:9. https://doi.org/10.47176/mjiri.35.9

\section{Introduction}

Herpes simplex virus type 1 (HSV-1) belongs to the herpesviridae family, which causes severe diseases, including oral-labial or oral-facial herpes, corneal blindness, encephalitis, and peripheral nervous system disorders. Also, HSV-1 causes difficult infections such as genital herpes in the genital or anal area. HSV-1 is a highly contagious infection, and most infected people suffer from

Corresponding author: Dr Mohammad Barati, m.barati@ajaums.ac.ir

1. Infectious Diseases Research Center, AJA University of Medical Sciences, Tehran, Iran

2. Department of Bacteriology and Virology, Faculty of Medicine, Semnan University of Medical Sciences, Semnan, Iran

3. Department of Medical Virology, Iran University of Medical Sciences, Tehran, Iran

4. Department of Physiology and Iranian Medicine, School of Medicine, AJA University of Medical Sciences, Tehran, Iran recurrent HSV infection several times a year $(1,2)$ Antiviral drugs can help to reduce the severity and frequency of symptoms, but as a result of the side effects of existing antiviral drugs and the increasing emergence of drug-resistant organisms during treatment, searching for an alternative antiviral agent is crucially necessary (3-5). Natural compounds have been considered as important

\section{$\uparrow$ What is "already known" in this topic:}

Due to some limitations of the present approved antiviral drugs against HSV-1, interest in discovering antiviral activity of natural compounds has recently been the subject of intense scientific investigation.

\section{$\rightarrow$ What this article adds:}

S. ebulus extract is a novel and effective natural compound in reducing $\mathrm{HSV}-1$ titer and can be considered as a potent inhibitor of HSV-1 infection. 
sources of potential treatments for cancer and infectious diseases due to their cost-effectiveness and potential therapeutic properties (6). Considering the undesirable side effects and drug-resistant organisms of antiviral agents, using an effective, economical, and accessible treatment is essential. Sambucus ebulus (S. ebulus), Iranian native botany, is one of the best natural compounds in the world that is a good source of polyphenols, anthocyanin, quercetin and vitamin $\mathrm{C}$, which may be related to its favorable properties such as antioxidant and antimicrobial activity $(7,8)$. Essential oils and monoterpene compounds from $S$. ebulus contains a-terpinene, g-terpinene, a-pinene, p-cymene, terpinen-4-ol, a-terpineol, thymol, citral and 1,8-cineole are responsible for the biological properties of medicinal plants, including anti-inflammatory, antiviral, antitumor, cytotoxic, and antimicrobial activities $(9,10)$. A wide range of medicinal applications of $S$. ebulus, including improvement of lipid profile, antiparasitic, antiviral, antibacterial, antiulcerogenic, anti-inflammatory applications, radical scavenging activities, and wound healing activities, has been reported (11-13). Sambucus ebulus (S. ebulus) grows in many temperate regions and does not require special conditions for maintenance and has amazing effects on humans. However, its subsistence may be surmised (14). Therefore, in this study, we evaluated the antiviral activity of $S$. ebulus hydroalcoholic extract on HSV-1 replication in cell culture system.

\section{Methods \\ Plant collection, extraction, and analyses of essential oils}

S. ebulus plant (Fruits) was collected from different parts of northern Iran and herbarium E1-38-131was registered in the Faculty of Pharmacy, Mazandaran University of Medical Sciences and its identity was confirmed by Mohamad Ali Ebrahimzadeh. In the next step, the fruits of the plant were dried at room temperature and pulverized in the grinder. Then, the $S$. ebulus extract was prepared by maceration method at room temperature for 3 days and the macerated solution was sterilized by $0.22 \mu \mathrm{m}$ microbiological filters. Also, the macerated solution was concentrated in a rotary evaporator until all the solvents were cleared. After preparation of the $S$. ebulus hydroalcoholic extract, quantitative and qualitative data for all the essential oils were determined by Shimadzu GC-14A gas chromatograph equipped with a Supelcowax 10 (Supelco, Bellefonte, PA) capillary column (60 m - 0.25 $\mathrm{mm}$ i.d.). Essential compounds were identified by comparing the mass spectra and their relative gaps with valid samples (the Wiley Registry of Mass Spectral data and literature citations) (15). Then, serial concentrations of S. ebulus extract were prepared to estimate its toxicity threshold and antiviral activity.

\section{Cell and virus culture}

In this study African green monkey kidney cells (Vero), taken from the Razi Vaccine and Serum Research Institute (Karaj, Iran), were used to evaluate the antiviral activity of the $S$. ebulus extract. Vero cells were grown under the following conditions: DMEM plus 10\% fetal bovine serum
(FBS; Gibco, USA); 2mM L-glutamine (Merck, Germany); $1 \mathrm{mM}$ sodium pyruvate (Merck, Germany); $100 \mathrm{IU} / \mathrm{mL}$ penicillin; and $100 \mu \mathrm{g} / \mathrm{mL}$ streptomycin (Sigma- Aldrich, USA) at $37^{\circ} \mathrm{C}$ in a humidified incubator in an atmosphere of $5 \% \mathrm{CO}_{2}$. The HSV-1 primary stock (strain KOS), a gift from the Virology Department of Tarbiat Modares University (Tehran, Iran) that was cultured in the Vero cells, and 50\% tissue culture infectious dose (TCID50) assay were used to determine the viral infectious titer.

\section{Cytotoxicity assay}

The cytotoxicity of $S$. ebulus extract on Vero cells was determined by methylthiazolyltetrazolium (MTT) method. First, Vero cells were grown in DMEM media with $10 \%$ FBS, and then harvested using trypsin and $100 \mu \mathrm{L}$ of trypan blue-treated cell suspension counted using hemocytometer. Then, Vero cells at a density of $1 \times 105$ cells $/ \mathrm{mL}$ were cultured on flat-bottomed 96-well microtiter plate (SPL Life Science, South Korea) in triplicate and incubated at $37^{\circ} \mathrm{C}$ in $5 \% \mathrm{CO}_{2}$ environment for 24 hours. Different concentrations from 25 to $225 \mu \mathrm{g} / \mathrm{mL}$ of $S$. ebulus extract were added to the plate and incubated for 48 hours. After treatment time, the $S$. ebulus extract was removed and replaced with $10 \mu \mathrm{L}$ of MTT reagent and $100 \mu \mathrm{L}$ RPMI (Bio-Idea, Iran). After 4 hours, medium was removed and $50 \mu \mathrm{L}$ of DMSO solution was added to the plate and the plate was gently shaken for 15 minutes. Finally, the plate was read at $550 \mathrm{~nm}$ using a microplate reader (Hiperion MPR 4+, Roedermark, Germany).

\section{Evaluation of antiviral activity}

The confluent monolayer of Vero cells in a flat-bottomed 96-well microtiter plate were preincubated with $100 \mu \mathrm{L}$ of $100 \mathrm{TCID} 50 / \mathrm{mL} \mathrm{HSV}-1$ in triplicate for 1 hour at $37^{\circ} \mathrm{C}$ in $5 \% \mathrm{CO}_{2}$ atmosphere. After attachment time, the media containing HSV-1 were discarded from the wells, and the cells were washed 3 times with PBS (PBS; Bio-Idea, Iran). Then, the infected cells were incubated with $100 \mu \mathrm{L}$ of different noncytotoxic concentrations of $S$. ebulus extract for 48 hours at $37^{\circ} \mathrm{C}$ in a humidified $5 \% \mathrm{CO} 2$ atmosphere. Also, the virus and cell controls were kept as described above. This assay was also performed for acyclovir. At the indicated time of all above experiments (at 48 hours), plates of cells were subjected to a single freezing-thawing cycle to release the cell-associated virus particles. Finally, the lysates were collected from the wells and used for TCID50 and quantitative real-time PCR methods to determine the amount of total progeny virus.

\section{Quantitative real-time PCR assay}

To determine HSV-1 viral load, HSV-1 DNA was extracted from the harvested lysates using Genomic DNA Extraction Mini kit (Favorgen, Taiwan), based on manufacturer's protocol. Then, DNA extracted was subjected to quantitative real-time PCR assay using HSV-1 specific primers for the US3 region, as described in previous study (1). This assay was performed using the Rotor-Gene Q instrument (Qiagen, Germany).

\section{Indirect immunofluorescence assay (IFA)}


Vero cells were seeded on sterile glass coverslips (Nunc, Denmark) in a 24-well plate (SPL Life Science, South Korea) and grown to $80 \%-90 \%$ confluence. The media were discarded and the cells were washed with PBS and incubated with $200 \mu \mathrm{L}$ of 100 TCID50/mL HSV-1 virus suspensions for 1 hour at $37^{\circ} \mathrm{C}$ in a humidified $5 \% \mathrm{CO} 2$ incubator. After discarding the virus inocula, the cells were washed 3 times with PBS. The maximum noncytotoxic concentration of S. ebulus extract was suspended in DMEM and was added to the wells and the plate was incubated at $37^{\circ} \mathrm{C}$ in $5 \% \mathrm{CO}_{2}$ atmosphere. The virus and cell controls were also included in this experiment. After 15 hours, the cells were fixed with cold acetone $\left(4^{\circ} \mathrm{C}\right)$ for 20 minutes, and the fixed cells were overlaid with HSV-1 specific human antibody, followed by incubation at $37^{\circ} \mathrm{C}$ for 30 minutes. In the next step, the cells were washed 3 times with PBS and were then overlaid with fluorescein isothiocyanate (FITC) (Dako, Germany), followed by incubation at $37^{\circ} \mathrm{C}$ for 30 minutes. Afterwards, the cells were washed 3 times with PBS and coverslips were mounted by glycerol buffer on slides. Finally, Olympus BH2-RFCA fluorescence microscope (Tokyo, Japan) was used to visualize the cells.

\section{Statistical analysis}

The mentioned values were obtained by the average of 3 independent experiments. The results of the experiments were tabulated and one-way analysis of variance (ANOVA) was used to analyze the difference between the means and Tukey's multiple comparison test was also performed. GraphPad Prism software, version 7.0 (GraphPad software, USA) was used for all analyses and $p$ values less than 0.05 were considered as statistically significant.

\section{Results \\ Gas chromatography (GC) and mass spectrophotometry (MS)}

A total of 28 compounds were identified in S. ebulus extract, and the main components of $S$. ebulus extract were $\alpha$-Terpinene, $\beta$-Pinene, $\alpha$-Terpineol, Trans carveol, Cis carveol, Chavicol, Terpinen-4-ol, and Iso borneol (Table 1). In this study all experiments were performed with the same lot of essential oil to ensure reproducibility due to the inherent variability observed from lot to lot.

\section{Cytotoxicity of extract}

MTT assay was used to determine the cytotoxic effect of different concentrations of $S$. ebulus extract on Vero cells. As shown in Figure 1, acyclovir did not show significant effects on Vero cells in the cytotoxicity test. In cytotoxicity experiments, acyclovir showed a significant reduction compared to the S. ebulus extract because by increasing the concentration of essential oils of hydroethanolic extracts, cell viability is significantly reduced. Thus, the viability was determined greater than $90 \%$ up to the concentration of $75 \mu \mathrm{g} / \mathrm{mL}$ of $S$. ebulus extract and these concentrations were used for subsequent antiviral assays.

\section{Antiviral activity of the extract}

In this study to evaluate $S$. ebulus extract with antiviral properties, we investigated the anti-HSV-1 activity (in vitro) of S. ebulus extract, prepared from $S$. ebulus collected in northern Iran. The antiviral activity was evaluated by 100 tissue culture infecting doses (TCID50) and qPCR realtime assays. The results of TCID50 assay showed the preexposure and coexposure of Vero cells to $S$. ebulus extract did not lead to any reduction of the HSV-1 titer.

\begin{tabular}{lccc}
\multicolumn{4}{l}{ Table 1. Gas chromatography and mass spectrophotometry of S. ebulus fruit extract } \\
\hline No & Compounds & KI $=$ Kovats Index on HP-5 column & Percent $(\%)$ \\
\hline 1 & Pino carvone & 1156 & 0.31 \\
2 & Iso pulegol & 1209 & 0.79 \\
3 & $\alpha$-Terpinene & 1125 & 1.28 \\
4 & Safrol & 1273 & 0.19 \\
5 & $\beta$-Pinene & 976 & 0.76 \\
6 & Iso estragol & 1254 & 1.39 \\
7 & Linalool oxide & 1121 & 0.74 \\
8 & Camphor & 1185 & 0.76 \\
9 & $\alpha$-Terpineol & 1211 & 2.76 \\
10 & Myrtenol & 1189 & 0.64 \\
11 & Verbenone & 1206 & 1.06 \\
12 & Fragranol & 1264 & 0.23 \\
13 & Trans carveol & 1195 & 0.65 \\
14 & $\alpha-$ Thujone & 1121 & 0.89 \\
15 & Geranial & 1165 & 0.95 \\
16 & Cis carveol & 1187 & 3.86 \\
17 & Geraniol & 1257 & 1.63 \\
18 & $\beta$-Thujone & 1095 & 0.98 \\
19 & Chavicol & 1253 & 2.43 \\
20 & Carvone & 1284 & 0.57 \\
21 & Myrtenal & 1124 & 0.42 \\
22 & Pulegone & 1263 & 1.18 \\
23 & Ocimenone & 1275 & 0.47 \\
24 & Ocimene oxide & 1071 & 1.16 \\
25 & Terpinen-4-ol & 1189 & 3.39 \\
26 & Borneol & 1205 & 1.05 \\
27 & Pulegol & 1189 & 0.17 \\
28 & Iso borneol & 1094 & 0.92 \\
\hline & & &
\end{tabular}




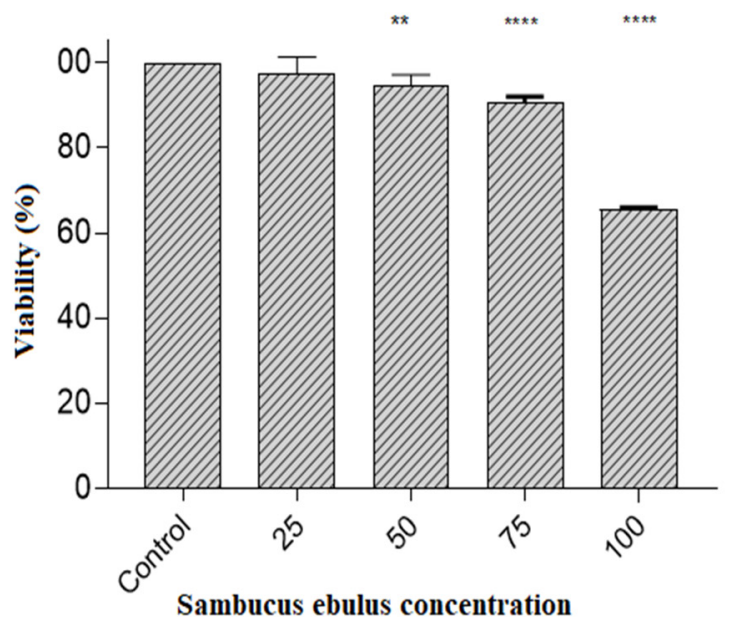

A

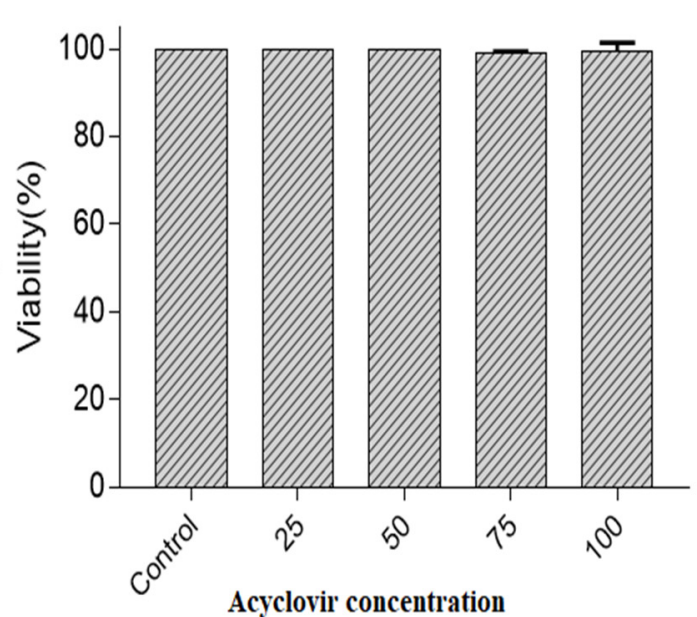

B

Fig. 1. Evaluation of cytotoxicity of $S$. ebulus (A), acyclovir as a positive control (B) on Vero cells

Meanwhile, virucidal activity was not observed at any of the studied concentrations of $S$. ebulus extract, indicating that S. ebulus extract could not directly inactivate the HSV1 particle and could lead to the inactivation of viral infection. The significant finding of our study is that $S$. ebulus extract exerts its antiviral effects only when added 1 hour after absorption of HSV-1 to the Vero cells, which could result in a striking decrease in viral titer. Postexposure of HSV-1 with $S$. ebulus extract at the concentrations of 25,50 , and $75 \mu \mathrm{g} / \mathrm{mL}$ showed that it could led to $0.5,1.2$, and $2.6 \log 10$ TCID50 reduction in virus titer when compared to the virus control, respectively $(\mathrm{p}<0.0001)$ (Fig. 2). In our study acyclovir was used as a positive control to compare the anti- HSV-1 activities of the test compounds. $Z$ test was used to confirm the results. In the next step, qPCR real-time assay was used to confirm the antiviral activities of $S$. ebulus extract against HSV-1 and

TCID50

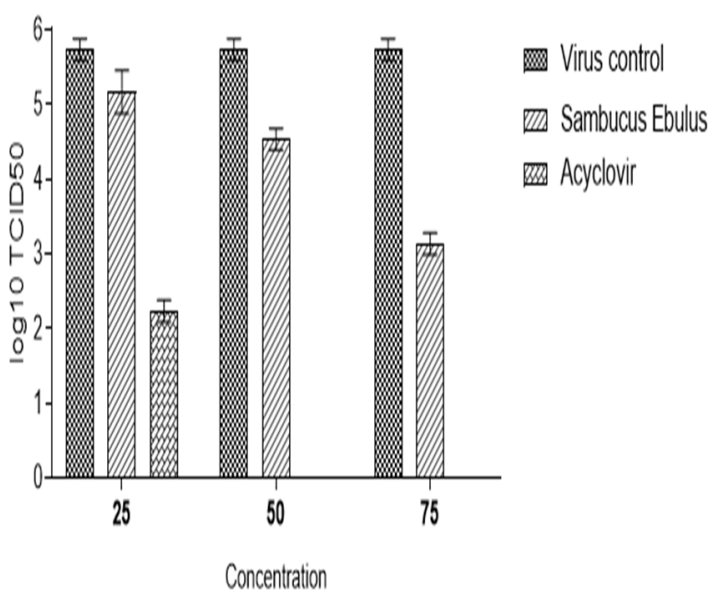

Fig. 2. Assessment of antiviral activity of S. ebulus on the infectious titer of HSV-1 by TCID50 assay, compared with acyclovir. the antiviral activity followed a dose-dependent pattern. Thus, the $S$. ebulus extract at the concentration of 25,50 , and $75 \mu \mathrm{g} / \mathrm{mL}$ led to inhibition rates of $4.2 \%, 48.2 \%$, and $91.2 \%$, respectively. The most antiviral effect of $S$. ebulus extract was observed at the concentration of $75 \mu \mathrm{g} / \mathrm{mL}$, which could lead to a $91.2 \%$ inhibition rate. The production of HSV-1 was completely inhibited by acyclovir at the concentration of $75 \mu \mathrm{g} / \mathrm{mL}$ (Fig. 3).

\section{Indirect immunofluorescence assay}

An indirect immunofluorescence assay (IFA) was used to evaluate the inhibitory activity of $S$. ebulus extract on the expression of HSV-1 antigens on the Vero cells surface. In this step, the highest nontoxic concentration of $S$. ebulus extract, which showed the highest inhibitory effect against the HSV-1, was used. Equally, both positive and negative controls were also included. Figure 4 shows a significant reduction in fluorescence emission intensity in HSV-1infected cell treated with $S$. ebulus extract at the

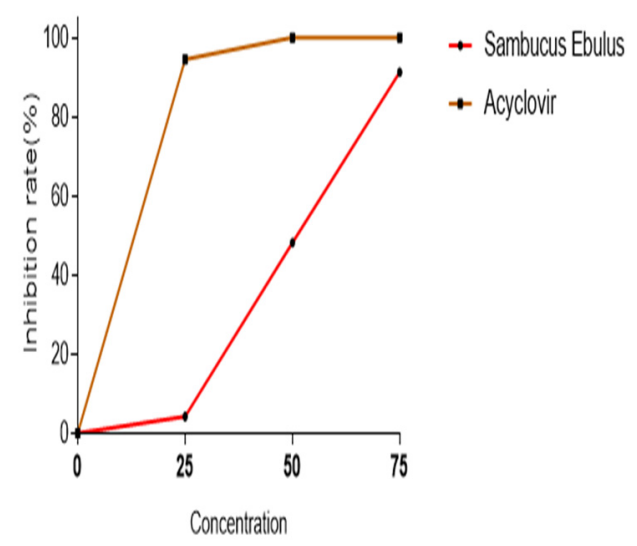

Fig. 3. Comparison of the inhibitory rates determined by real-time PCR assay in the postexposure of HSV-1 with S. ebulus and acyclovir 

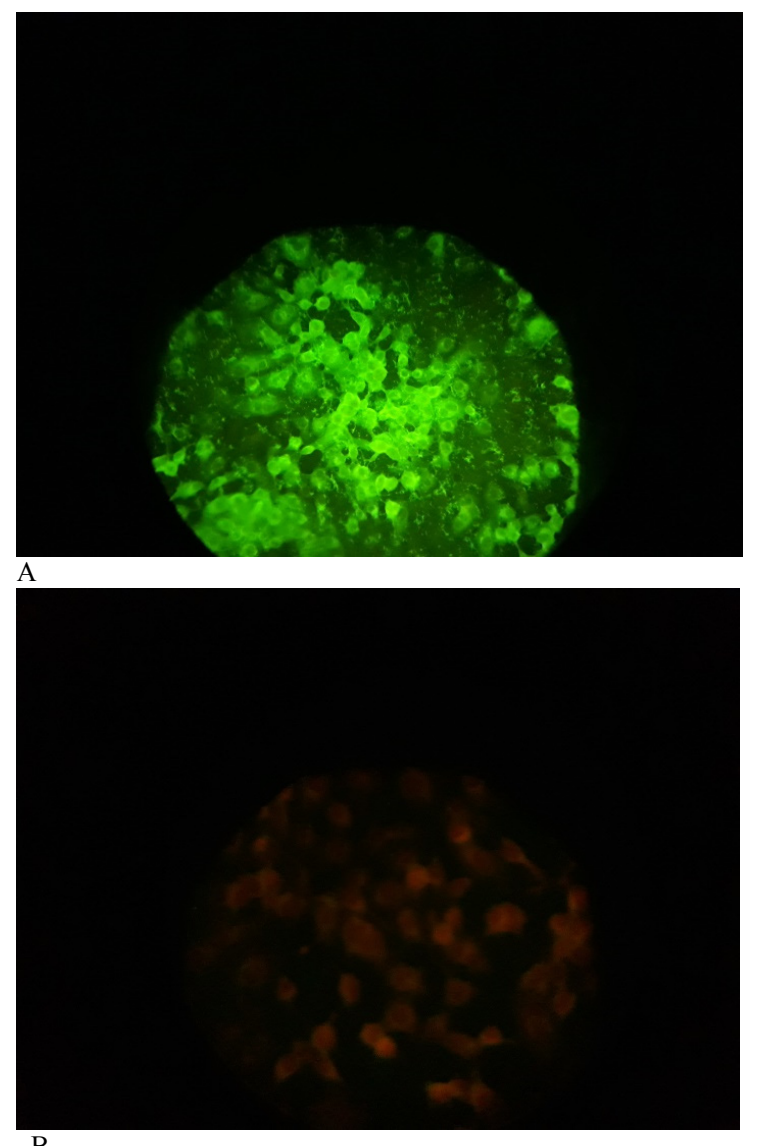

B

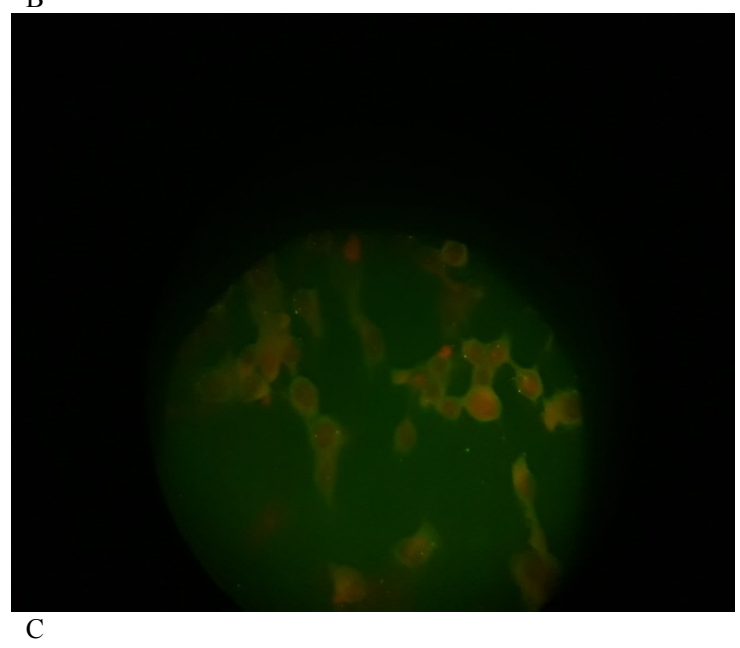

Fig. 4. Indirect immunofluorescence assay for detection of HSV-1 antigens in the Vero cells. (a) Virus control, (b) Cell control, (c) Infected cells treated with $S$. ebulus extract $(75 \mu \mathrm{g} / \mathrm{ml})$ at $15 \mathrm{~h}$ post infection.

concentration of $75 \mu \mathrm{g} / \mathrm{mL}$ compared to the positive control.

\section{Discussion}

The HSV-1 infection is a significant global public health problem. Antiviral drugs used to treat HSV-1 infection are weakened due to major side effects and the emergence of drug-resistant strains during treatment. Hence, the research and development of effective HSV-1 drugs especially from the natural product seems interesting and necessary (16, 17). Compared to the current antiviral drugs, there are several important advantages to use natural product for therapeutics, such as effectiveness in low concentrations, potent antiviral activity against drug-resistant strains, and cost effective preparation $(18,19)$. In this study we used HSV-1 (strain KOS) as the virus model and evaluated the antiviral properties of $S$. ebulus extract on HSV-1. Therefore, a series of laboratory experiments were designed and performed based on the cell culture system. The plant S. ebulus (Caprifoliaceae L.) as a native and wellknown Iranian herb is abundant in northern Iran and has been noted to exhibit exceptional antimicrobial and antiparasitic functions (20-23). Also, it consists of anticancer substances, such as ebulin (RIP-II, ribosome inactivated protein-II), flavonoids, steroid substances, cardiac glycosides, tannins, caffeic acid derivatives, and other isolated substances (24). To date, several studies have reported the inhibitory capacity of the Caprifoliaceae family on viral infections.

Essential oils from S. ebulus are complex natural mixtures and their main terpenes, such as $\alpha$-Terpinene, $\beta$ Pinene, $\alpha$-Terpineol, Trans carveol, Cis carveol, Terpinen4-ol, Iso borneol, and phenylpropanoids, are responsible for their biological properties and their major monoterpene compounds have been scientifically proven to possess antiviral activity. These compounds interact with the viruses and could alter the intracellular events of virus replication. Previous studies have reported a potent antiviral activity of terpenes such as Isoborneol that specifically inhibit glycosylation of viral polypeptides (15, 25). In the study by Christian Krawitz et al, the inhibitory activity of $S$. nigra L. against influenza A and B viruses was investigated in vitro (26). Their results have shown that the aqueous extract displays an inhibitory effect on the propagation of human pathogenic influenza viruses. They suggested that additional investigations are required to elucidate the mechanism of action. In another study by Christie Chen et al, antiviral properties of $S$. nigra extracts were tested for anti-infectious bronchitis virus activity on Vero cells and a dose-dependent antiviral activity were found in their investigation (27). The results of their study suggest that S. nigra extract may inhibit IBV at the onset of infection by presenting a noninfectious virus. In our study, we aimed to assess the antiviral activity of $S$. ebulus extract at different time of the virus replication cycle, so that the $S$. ebulus extract was added before and after virus adsorption. Our results have shown in preexposure and coexposure of cells to $S$. ebulus extract did not result in any decrease in the titer of HSV-1 and exerted its own antiviral effects only when added 1 hour after infection of the cells, which can significantly inhibit HSV-1 infection in the Vero cell culture system. The inhibitory of $S$. ebulus extract was confirmed by several laboratory techniques, containing TCID50, real-time PCR, IFA, and CPE inhibition assays. Previous studies have shown that after HSV-1 entry into a host cell, it transports its nucleocapsid through the nuclear pores from the cytosol to the cell nucleus. HSV-1 then completes viral gene expression, replication, capsid formation, and viral DNA packaging in the nucleus of infected cells. Our experiments showed that the most antiviral potency is observed after viral adsorption. S. ebulus 
extract may be targeted and interfere with some stages in the life cycle of the HSV-1, such as DNA, RNA, and protein synthesis, which occurs after viral adsorption and internalization by the cells, leading to inhibition of intracellular replication $(28,29)$. The comparison between our results with those of Gavanji et al in 2015 shows that $S$. ebulus extract is more effective than $\mathrm{Z}$. multiflora and $\mathrm{E}$. caesia; and anti-HSV-1 activity of these oils showed that by increasing the concentration of oils, virus infection is inhibited. Thus, it can be concluded that the antiviral effect of different plant oils is related to their active components and natural phenolic compounds of oils have ideal antimicrobial activity (30). Additional investigations are required to explore the exact antiviral mechanism of the $S$. ebulus extract, such as transmission electron microscope (TEM), and to examine the pattern of HSV-1 gene expression in the presence of the $S$. ebulus extract.

\section{Conclusion}

In this study the inhibitory activity of SE-HAE on HSV1 was investigated for the first time. The results showed $S$. ebulus extract have a high anti- HSV-1 activity with low cytotoxicity, suggesting that the $S$. ebulus extract can be effective in enhancement of antiviral effects against HSV1. The results of in vitro experiments in the present study also showed that the $S$. ebulus extract have inhibitory effects against HSV-1only after the virus entered the host cells.

\section{Acknowledgement}

The study was financially supported by AJA University of Medical Sciences (Grants No. IR.AJAUMS.REC. 1398.029).

\section{Conflict of Interests}

The authors declare that they have no competing interests.

\section{References}

1. Man A, Slevin M, Petcu E, Fraefel C. The cyclin-dependent kinase 5 inhibitor peptide inhibits herpes simplex virus type 1 replication. Sci Rep. 2019;9(1):1-8.

2. Medini F, Legault J, Pichette A, Abdelly C, Ksouri R. Antiviral efficacy of Limonium densiflorum against HSV-1 and influenza viruses. S Afr J Bot. 2014;92:65-72.

3. Yousefi B, Valizadeh S, Ghaffari H, Vahedi A, Karbalaei M, Eslami M. A global treatments for coronaviruses including COVID-19. J Cell Physiol. 2020.

4.El-Toumy SA, Salib JY, El-Kashak WA, Marty C, Bedoux G, Bourgougnon N. Antiviral effect of polyphenol rich plant extracts on herpes simplex virus type 1. Food Sci Hum Well. 2018;7(1):91-101.

5. Ghaffari H, Tavakoli A, Moradi A, Tabarraei A, Bokharaei-Salim F, Zahmatkeshan M, et al. Inhibition of H1N1 influenza virus infection by zinc oxide nanoparticles: another emerging application of nanomedicine. J Biomed Sci. 2019;26(1):70.

6. Esghaei M, Ghaffari H, Esboei BR, Tapeh ZE, Salim FB, Motevalian M. Evaluation of anticancer activity of Camellia sinensis in the Caco-2 colorectal cancer cell line. Asian Pac J Cancer Prev. 2018;19(6):1697.

7. Quave CL, Plano LR, Bennett BC. Quorum sensing inhibitors of Staphylococcus aureus from Italian medicinal plants. Planta Med. 2011;77(02):188-95.

8. Tasinov O, Kiselova-Kaneva Y, Ivanova D. Sambucus ebulus-from traditional medicine to recent studies. Scr Sci Med. 2013;45(2):36-42.

9. Astani A, Reichling J, Schnitzler P. Comparative study on the antiviral activity of selected monoterpenes derived from essential oils. Phytother
Res. 2010;24(5):673-9.

10. Silva ACRd, Lopes PM, Azevedo MMBd, Costa DCM, Alviano CS, Alviano DS. Biological activities of a-pinene and $\beta$-pinene enantiomers. Molecules. 2012;17(6):6305-16.

11. Ivanova D, Tasinov O, Kiselova-Kaneva Y. Improved lipid profile and increased serum antioxidant capacity in healthy volunteers after Sambucus ebulus L. fruit infusion consumption. Int J Food Sci Nutr. 2014;65(6):740-4.

12. Salehzadeh A, Asadpour L, Naeemi AS, Houshmand E. Antimicrobial activity of methanolic extracts of Sambucus ebulus and Urtica dioica against clinical isolates of methicillin resistant Staphylococcus aureus. Afr J Tradit Complement Altern Med. 2014;11(5):38-40.

13. Schwaiger S, Zeller I, Pölzelbauer P, Frotschnig S, Laufer G, Messner $\mathrm{B}$, et al. Identification and pharmacological characterization of the antiinflammatory principal of the leaves of dwarf elder (Sambucus ebulus L.). J Ethnopharmacol. 2011;133(2):704-9.

14. Jiménez P, Tejero J, Cordoba-Diaz D, Quinto EJ, Garrosa M, Gayoso MJ, et al. Ebulin from dwarf elder (Sambucus ebulus L.): A minireview. Toxins. 2015;7(3):648-58.

15. Elaissi A, Rouis Z, Salem NAB, Mabrouk S, ben Salem Y, Salah KBH, et al. Chemical composition of 8 eucalyptus species' essential oils and the evaluation of their antibacterial, antifungal and antiviral activities. BMC Complement Altern Med. 2012;12(1):81.

16. Latief MA, Chikama T, Ko JA, Kiuchi Y, Sakaguchi T, Obana A. Inactivation of acyclovir-sensitive and-resistant strains of herpes simplex virus type 1 in vitro by photodynamic antimicrobial chemotherapy. Mol Vis. 2015;21:532.

17. Pan D, Kaye SB, Hopkins M, Kirwan R, Hart IJ, Coen DM. Common and new acyclovir resistant herpes simplex virus-1 mutants causing bilateral recurrent herpetic keratitis in an immunocompetent patient. J Infect Dis. 2014;209(3):345-9.

18. Lin LT, Hsu WC, Lin CC. Antiviral natural products and herbal medicines. J Tradit Complement Med. 2014;4(1):24-35.

19. Yildirim A, Duran GG, Duran N, Jenedi K, Bolgul BS, Miraloglu M, et al. Antiviral activity of hatay propolis against replication of herpes simplex virus type 1 and type 2. Med Sci Monit: international medical journal of experimental and clinical research. 2016;22:422.

20. Rahimi-Esboei B, Ebrahimzadeh M, Gholami S, Falah-Omrani V. Anti-giardial activity of Sambucus ebulus. Eur Rev Med Pharmacol Sci. 2013;17(15):2047-50.

21. Rodino S, Butu A, Petrache P, Butu M, Dinu-Pirvu C-E, Cornea CP. Evaluation of the antimicrobial and antioxidant activity of Sambucus ebulus extract. Farmacia. 2015;63(5):751-4.

22. Gholami S, Rahimi-Esboei B, Ebrahimzadeh M, Pourhajibagher M. In vitro effect of Sambucus ebulus on scolices of Hydatid cysts. Eur Rev Med Pharmacol Sci. 2013;17(13):1760-5.

23. Daryani A, Ebrahimzadeh MA, Sharif M, Ahmadpour E, Edalatian S, Esboei BR, et al. Anti-Toxoplasma activities of methanolic extract of Sambucus nigra (Caprifoliaceae) fruits and leaves. Rev Biol Trop. 2015;63(1):07-12.

24. Shokrzadeh M, Saravi SS. The chemistry, pharmacology and clinical properties of Sambucus ebulus: A review. J Med Plants Res. 2010;4(2):95-103.

25. Brand YM, Roa-Linares VC, Betancur-Galvis LA, Durán-García DC, Stashenko E. Antiviral activity of Colombian Labiatae and Verbenaceae family essential oils and monoterpenes on Human Herpes viruses. J. Essent Oil Res. 2016;28(2):130-7.

26. Krawitz C, Mraheil MA, Stein M, Imirzalioglu C, Domann E, Pleschka $\mathrm{S}$, et al. Inhibitory activity of a standardized elderberry liquid extract against clinically-relevant human respiratory bacterial pathogens and influenza $\mathrm{A}$ and $\mathrm{B}$ viruses. BMC Complement Altern Med. 2011;11(1):16.

27. Chen C, Zuckerman DM, Brantley S, Sharpe M, Childress K, Hoiczyk E, et al. Sambucus nigra extracts inhibit infectious bronchitis virus at an early point during replication. BMC Vet Res. 2014;10(1):24

28. Maruzuru Y, Shindo K, Liu Z, Oyama M, Kozuka-Hata H, Arii J, et al. Role of herpes simplex virus 1 immediate early protein ICP22 in viral nuclear egress. J Virol. 2014;88(13):7445-54.

29. Pellett PE, Roizman B. Herpesviridae. Fields Virology. 2013;2(6):1802-22.

30. Gavanji S, Sayedipour SS, Larki B, Bakhtari A. Antiviral activity of some plant oils against herpes simplex virus type 1 in Vero cell culture. J Acute Med. 2015;5(3):62-8. 